\title{
How to Carve a King: Janna's Inscription in the Temple of Amṛteśvara
}

\author{
Elena Mucciarelli | ORCID: 0000-0003-3822-2277 \\ Assistant Professor for Hinduism in the Sanskrit Tradition, Gonda Lecturer, \\ Faculty of Theology and Religious Studies, University of Groningen, \\ the Netherlands \\ e.mucciarelli@rug.nl
}

\begin{abstract}
The article provides a reading of a twelfth-century inscription composed by a courtly poet in Karnataka. At its most rudimentary level, the inscription praises the king and glorifies his commander. However, a closer reading demonstrates the poet playing with the conventions of his time. One of the techniques used to enhance the power of the ruler was to represent the commanders as replicas of their king. The author turns this mechanism into the inscription's poetic motif. He uses the very dynamic of reduplication to subtly show the limits in the construction of power.
\end{abstract}

\section{Keywords}

Janna - Karnataka - Ballāḷ II - Amṛteśvara - inscription - poetics

Strange that the ordinary, worn-out ways

Of every day encompass the imagined

And endless universe woven by reflections.

BORGES, "Mirrors" 


\section{Introduction}

Texts and symbols carved in stone are a near universal feature of human culture and are extraordinarily rich instances of early multi-mediality. While such inscriptions are fundamental especially for the study of ancient periods, they have been used as a form of communication throughout human history. For some historical phases, epigraphic material stands as the only source of textual information of that period, and are thus used, for instance, to partially reconstruct the economic or the religious system of certain civilizations. Moreover, these epigraphic materials often represent the first attestations of a language's usage and have shown to withstand the vagaries of time better than many other media. These conditions have fostered a kind of functionalism towards inscriptions, as if they were only a repository of information to be investigated and deciphered. Rarely, however, have they been read in relation to their materiality. ${ }^{1}$ This article attempts to do just that.

As far as the Indian Subcontinent is concerned, inscriptions have been amply used as sources of data for the reconstruction of political, economic, and cultural history. ${ }^{2}$ Lately, increasingly specific documentation ${ }^{3}$ and analysis on local corpora have been attempted, for example on the Tamil epigraphic corpus (see, e.g., Murugaiyan 2012). At the same time, new approaches to the understanding of inscription and its materiality have been proposed, along with a range of methodological reflections: What is an inscription? Should we consider only the information it transmits? How do we deal with its materiality, including its relation to the space it occupies? These questions place us beyond the familiar landscape of our thoughts and practices. ${ }^{4}$

1 According to the German Media Theory, media (as channel) is the materiality of the ontologising (see Siegert 2015). The "inscriptionality" of the inscription is the most central feature of the inscription. We should read its words as an act of encoding on stone a full set of meanings. Looking at inscriptions in this way, allows us to see them in their three-dimensionality. And to think of the intent of their composers differently. Studies have been done on epigraphy as media recently in the Greek and Roman traditions: see Meyer 2011, Roda 2012, Berti et al. (eds.) 2017 .

2 For a crucial introductory overview on the scope and significance of Indian epigraphy, see Sircar 1965 and Salomon 1998.

3 For a selection of the collection of epigraphic corpora, apart from the basic collection of the Epigraphia Indica, see: Early Inscriptions of Āndhradeśa: http://hisoma.huma-num.fr/exist/ apps/EIAD/index2.html; South Asian Inscriptions Database: http://siddham.co.uk. More recently, see https://dharma.hypotheses.org/epigraphical-resources.

4 On such questions, see the inspiring idea of Panciera (2012) of inscriptions as loci of a deviant language. More specifically on the materiality of inscriptions with respect to Kannada inscription, see Settar 2014. 
One important answer to the first question posed about epigraphic material is that inscriptions are to be understood as public narrative. And, as public narratives, inscriptions and their eulogistic sections (praśasti), particularly from the beginning of the first millennium CE, entailed epithets, genealogies of rulers, and foundation legends. Kings tried to historicize and enhance their rulership by tracing their dynasty back to a significant event, the foundation legend. Such events-often entailing divine intervention-display the origin of their power. At the same time, this narration stood as the starting point for the serialization process (genealogy), creating histories in which the rulers could place themselves. Thus, systematic analysis of this material has produced a better understanding of, for example, royal discourse, the construction of charisma, and religious patronage (see, among others, Francis 2013 and Schmidchen 2014). Moreover, as Pollock (2006) has pointed out, there are reasons to read inscriptions using the tools we use to read kārya - the development of the Sanskrit language into a form of literary and literate artistic production. ${ }^{5}$ In their full-fledged form, they share some features of this literary modality. In this sense, the choice of language(s) of the inscriptions and the usage of specific stylistic constructions have been recently analyzed, generating important new understandings of the representation of modes of power in pre-modern India (Pollock 2013 and Cox 2016).

Taking into consideration precisely these new conceptualizations of the epigraphic material, especially that of Cox 2016, I suggest the following: if epigraphic production is not only a database of historical information or a token of culture-power formation, the inscriptions should be read and interpreted accordingly —in other words, as literary production comprising different levels of interpretations. Thus, my aim is to approach any text of epigraphic corpus in its entirety through the prism of literary critique and to locate such texts in their full historical context. Driving this approach is the notion that ancient epigraphic production operated as expressive media in the projection of power by rulers, all the while embedding individual voices. I am not arguing that each and every carved stone was a self-conscious poetic production, but rather that some of them were. Among these productions, some were beautifully composed, others were conventional, and some were quite insignificant—as is true for all literary corpora.

In this article, I provide a reading of a twelfth century inscription that represents a case in point. Its author, Janna, was one of medieval Karnataka's most

5 The idea of inscription as literature has been suggested by Salomon (1998), though he limited his definition to the praśasti part (the eulogy) and considered it as "more a labor of daily bread than of love" (Salomon 1998: 236). 
important poets. At its most rudimentary level, Janna's inscription praises the king and glorifies his commander. However, a closer reading demonstrates how the poet built within the text a complex web of references to his other compositions and to shared literary topoi as well as to his court patrons. How should we read the message of Janna's text made public by this inscription? Is he really celebrating the power of the king and his elite or is he playing with the conventions of the time that insisted on the mechanism of reduplication to enhance the image of the ruling elites? Arguably each and every inscription could be seen as an embodied replica of a text that has been already uttered or composed elsewhere. We might add that inscriptions are also the source of future replicas disseminated by those who will read them. Janna seems to take these features of epigraphic production and develop them throughout his composition. I would argue that Janna consciously turns the dynamic of reduplication into the underlying rationale of the inscription, by way of which we are exposed to the cracks in the construction of power.

During the reign of Vīra Ballāla II Hoysala (1173-1220), the territory of modern Karnataka, together with its neighboring regions, underwent continual political change. ${ }^{6}$ Under the king that patronized our poet, the Hoysala lineage had obtained independence from their Câlukya overlord in the north, taking advantage of a power vacuum following the death of Tailapa III Câlukya in $1163 .{ }^{7}$ Around the years $1175^{-1180}$, Ballạla II managed to gain control over the Coorg area and subjugate the Cangalva. After securing the southern part of Arakalagud district, he prevailed over the Kongālva and aimed northwards, reconquering the territory of the Pandya of Nolambavādi. These victories paved the way to fighting against and partially winning the Kalacurya, the Câlukya, and the Yādava. Overall, Ballāla II massively expanded the borders of the Hoysala kingdom: he controlled the Ganga territory in the south and south-east, central Karnataka up to the Western Ghats, the Tulunadiu on the coastal Karnataka, and the north up to Banavase.

At the same time, Halebid, ${ }^{8}$ one of the two capitals, was being established as a center and as a court connected with a number of trading centers, which

6 For an overview of the period, see, among others, Kulke 1993 and 1995; Sastri 2005.

7 See Coelho 1950: 148-151.

8 See Kasdorf 2013. 
acted as economic, administrative, and commercial hubs. ${ }^{9}$ Against this political and economic backdrop, there was a flourishing of the intellectual, literary, and artistic seeds that were implanted at the time of Viṣnuvardhana (11041141), the grandfather of Ballạla II and the first to establish Hoysaḷ rule. ${ }^{10}$

This floruit can be further traced to a religious shift that redefined the cultural landscape. The Śivabhakta movement ${ }^{11}$ challenged temple-based religious practices and ruptured Jaina intellectual hegemony (already partially shared with the Brahmins). The rich contributions of the Vacanakāras (vacana poets), such as Basavanna, as well as of authors like Harihara, ${ }^{12}$ awakened a new societal consciousness and changed the course of Kannada literature. In fact, the Śaivabhakta developed a form of literary production that was connected to the oral tradition and intended for a diverse audience. ${ }^{13}$

Summing up this brief excursus, the court in which Janna lived enjoyed significant territorial expansion, a flourishing urban economy, vibrant religious movements, and a new literary vitality. ${ }^{14}$ At the same time, Ballạla II continued his grandfather's strategic communicative practice, based on the use of a specific sandstone for the construction of temples. During Viṣnuvardhana's reign, between 1104 and 1141, a unique architectural style developed that displayed elaborated ornamentation and minute sculptural craft. ${ }^{15}$ The stone of the sacred areas demonstrate extraordinary architectural achievement. More than that, however, they convey a constitutive means of strategic communication, that of epigraphic production. ${ }^{16}$

9 The merchants in the Hoysala period were so wealthy that they have been compared, somewhat hyperbolically, to Kubera (the lord of wealth). Hoysala Setti and Nemi Setti were royal merchants (rājasresthigal) in the court of Vishnuvardhana.

10 Nemicandra's most famous and important text is the Lìlâvati Prabandham, composed when was he was still at the court of Lakșmaṇarāja. This text, based on the Vāsavadatta by Subandhu, betokens a new literary scene. In 1218, Rudrabhațta composed Jagannātha Vijaya, a Kannaḍa campūkārya dedicated to Ballāla II (see Ali 1972: 292ff).

11 On what was later called the "Lingayat" or "Vīraśaiva" movement, the beginnings of which can be traced to twelfth-century north Karnataka, see Michael 1983: 309-322. As for the connection between Vīraśaiva and other Śaiva bhakta movements in South India, see Ben-Herut 2015: 274-295, Fisher 2017 and Ben-Herut 2018.

12 Harihara authored various Ragale poems on the lives of many Śaivabhakta-s. On the significance of Harihara's work in relation to the development of the Śaivabhakta movement in Karnataka and the connection with the same tradition in South India, see Ben-Herut 2015.

13 For the development of Kannadia literature, see Nagaraj 2003.

14 On the flourishing period of the Hoysala reign we have also some accounts in Canna Basava Purāṇa by Virūpākṣa 62,51.

15 See Evans (1997) for a study on the narrative panels of the main Hoysala temples.

16 See Mucciarelli 2017 . 
The intellectual blossoming of this period was signaled not only by the outstanding literary production, but also by the development of public narrative into a highly sophisticated form of expression. Already during Viṣnuvardhana's rule, inscriptions were a frequent feature of the cultural map, and by the time his nephew ascended the throne, the number of poets composing inscriptions, including Dēvappaya ${ }^{17}$ and Śrī Vikramapaṇịta, had markedly increased. Moreover, while the inscriptions of the period were a means to present a strong image of the king, in doing so, they also became an arena for literary experimentation.

One exemplary case is that of Janna, one of the greatest Jaina poets of Kannadia literature. ${ }^{18}$ Janna lived at the court of Ballāla II and then at that of Ballāla II's son, Vīra Narasimha II (1217-1235), serving as minister, soldier and poet: "If I am inside the court of the king Narasimha, fighter of the Cọla clan, who knows all, I am a commander-in-chief; if I sit I am a minister, if I start to do my work [to write], I am the poet Janārdana". Thusly Janna portrays himself in one of his religious texts, the Anantanātha Purāna (v. 56): a complex figure at once fulfilling different personas comprised of courtly obligations and desires toward literary experimentation.

Janna authored two "religious" texts, the Anantanātha Purāṇa (1230 AD) and the Yaśôdhara carite (1209 AD), breaking the tradition set by Pampa to write one àgamika (religious) and one laukika (worldly) composition. Apart from these, Janna also authored a treatise on erotics, the Anubhava mukura. In the Yaśödhara carite, a short poetic work, Janna for the first time moved away from the campu genre (a mixture of verse and prose) that was the common practice in Kannadia literature, and instead choose a meter adapted from the Prakrit tradition, the kanda. ${ }^{19}$ But the novelty of the poem is not on the metrical level alone. Although it presents itself as a re-adaptation of a well-known Jaina story with variants in Prakrit, Sanskrit ${ }^{20}$ and Tamil, it stands as a unique formula-

17 Dēvappaya composed, for instance, the inscription found near the basadi of Arsikere to celebrate the coronation of Ballāla in 1173 .

18 For a general introduction to Janna, see Ramachandra \& Rai 2015 and Krishnakumar (ed.) 2007, who collected all extant productions of Janna.

19 Only the last verse of each section (avatära) is in vrtta type meter. Yaśödhara carite is perhaps the only extant $m e l v a \bar{d} u$, that is, according to the definition given by Nāgavarma in the Kāryālōkanam, a poem consisting of more $p \bar{a} d u[15,25$ stanzas form a $p \bar{a} d u]$; it is composed in a single meter and is sung with or without instrumental accompaniment (see also Narasimhacarya 1988: 13).

20 Although he didn't state it explicitly, Janna patently drew inspiration from the eleventhcentury Sanskrit version by Vādirāja. 
tion of the narrative, revealing much of Janna's poetic flair. A brief $\operatorname{look}^{21}$ at the Yaśōdhara carite allows us to contextualize the analysis of the inscription within the broader landscape of Janna's literary world.

The Jaina story, as we know it also from other sources, concerns a king and his mother who condemned themselves to a series of reincarnations. This represents in Janna a narrative frame that surrounds the core of his creation. The story opens with the king Māridatta, who is a devotee of the bloodthirsty goddess Māri. He is just about to embark on a yearly sacrifice of human victims to the goddess, but we see that among those to be killed are two children who appear to be smiling. Māridatta's curiosity is piqued and he questions them. This is the departure point for an extended flashback narrated by one of the children, who is revealed as the reincarnation of the king Yaśodhara. The other child is Yaśodhara's mother. They both underwent a series of reincarnations, as they were guilty of samkalpahimse, or an imagined or intended act of violence. ${ }^{22}$ Māridatta, after hearing the story of all the incarnations that Yaśodhara and the queen went through, converts to the Jaina path of non-violence.

Janna's version of the story deviates from the others by paying particular heed to two moments: the first is the preparation of the annual blood sacrifice to the goddess Māri or Māriyamma. The poet uses vivid images, which extend far beyond traumatic realism into a visionary hyperrealism. This initial scene sets up a graphic scenario in which the characters will act and narrate the vicissitudes of Yaśodhara. Second, Janna zeroes in on the root of the violence: the queen's infatuation with the guardian of the elephants, the Mahout. This part exhibits, I suggest, an illuminating aspect of Janna's worldview. Consumed by his wife's betrayal, the king, at the urging of his mother, seeks consolation in the performance of a sacrifice.

In order to understand the Yaśödhara carite, we have to look at the core of the text, where Janna puts his poetic efforts and where his peculiar imagery is given free rein. As it turns out, the topic of non-violence, which is central to the Jaina tradition, ${ }^{23}$ represents a narrative frame rather than the heart of the

21 A full-fledged analysis of the Yaśôdhara carite is part of a larger research project that goes beyond the scope of this article.

22 Samkalpahimse, "violent (sacrifice) through imagination/intention," refers to the concept that samkalpa (intention, imagination) is a fundamental constituent of ritual performance. Samkalpa represents the defining frame of ritual and therefore is believed to have an agency in itself (see Michaels 2015).

23 This story is used in a common Jaina ritual, the Jivadayāstami nōmpi, and was part of the common shared knowledge as it appears in a panel along with episodes of Rāmāyaṇa and Māhābharata in the Mallikarjuna temple of Pattadakal (I thank Naresh Keerthi for 
work. The kernel of the story operates as a source of questions that deals with two sets of problems on two different levels: one treats the possibility of perpetrating violence, the value of responsibility, and the capacity to control the subsequent course of events. Another set of questions deals with the mechanisms of love, of falling in love, of betrayal, and, more deeply, with the fine substance of reality. The betrayal of the princess that instigates the sacrificial situation is displayed with great delicacy, revealing to us one of the central motifs of Janna's poetics. In the second chapter of the Yaśôdhara carite, the poet describes the first encounter of the princess with the guardian of the elephant, one built entirely on the auditory sense. No glances are exchanged; it is sound that will immediately and powerfully reach out to the mind. What seems to capture the interest of Janna is the way in which love comes to us, even when nothing seems to leave room for it: the princess hears the voice of the mahout, to whom she will lose her heart, just as she is embracing her husband, whom she deeply loves.

[...] while he was singing for pleasure; as if the soft melodious voice was a katakabija (seeds used to clarify the water) for her sleep, she, with eyes of a deer, listened, clearing up the dark water of her sleep and immediately donated as a gift her fascinated mind.

Yaśōdhara carite $2.28^{24}$

The singing voice of the Mahout - the guardian of the elephants — manages to insinuate itself between the princess and the king, although they are so tightly united that drops of sweat are falling from their bodies clasped together. The royal couple is apparently indivisible, and yet the music of the mahout sneaks in the non-space between the two lovers.

If we think again of the purely aural, and yet deeply devastating, encounter with the guardian of the elephant in the Yaśödhara carite, the world the poet presents us with is that of physical experience. For Janna, reality is to be experienced through the senses. In the case of the princess, the wife of Yaśodhara, sound shapes her mind to the point that even when the maiden tells her that her beloved is actually an ugly—almost monstrous—kind of Hunchback of Notre Dame, the princess is absolutely steadfast. Indeed, she reproaches the

pointing me out this sculptural adaptation of the story). See https://nishaamit.wordpress .com/2016/o8/25/pataddakal-majestic-era-of-temple-architecture/.

24 binadake pāduttire nu | ṇdani nidrage katakabüjamāytene mrgalō | cane tilidālisi muțtida | mana[mane] [maṃ] toțtane pasāyadānamgoțta! \| 
maiden: would she blame the rainbow for being crooked?25 The sensory experience has a high status in the ordo cognoscendi; reality is built upon it, and subsequent decisions are taken on this basis. The princess breaks her chastity and sets in motion a long chain of calamities for herself and for the king.

\section{The Poet and the Stone: Janna's Inscription in the Amṛteśvara Temple}

Bearing in mind these aspects of Janna's poetics, we shall now move to the epigraphic material that is the focus of this paper. One might wonder if Janna's highly subjective and phenomenological attitude is also found in the way he deals with royal power. Such a question bears particular significance when analyzing the relation between expressive media as a form of strategic communication and the singularity of the poet's voice. As already noted, Janna enjoyed an intimate association with his court of residence. More than once in Yaśôdhara carite, he refers to Ballāla II, properly praised in the first canto, as his master:

When Kṛșna/Kanna ${ }^{26}$ gave with respect, Ponna received; when Tailapa ${ }^{27}$ gave with profound love, Ranna received; when Ballạla gave with consideration (mannisi), Janna received the title of "Kavicakravartin".

Yaśōdhara carite $1.21^{28}$

This distinctive proximity to the king is not shared, for instance, by another key figure of the intellectual scene, Rāghavānika, ${ }^{29}$ who also lived during the Hoysala reign (probably under Narasimha I), but who was never a courtly poet.

25 karidādoḍe katturiyam / muruḍādoḍe malayajamgaḷạ koṃkidoḍem | smaracāpamanilikayvare / muruḷe pollameye lēsu nallara meyyo! (Yaśōdhara carite 2.42) "Would people cast aside the kasturi musk because it is black? Or the sandalwood because it is pungent / because its branches are crooked? Or the rainbow because it is curved? O foolish! The very blemishes become enhancing in the body of the person we love".

26 Kṛ̣na III, emperor of the Raștrakuta (939-968), granted the title Kavicakravarti to Ponna.

27 Cạlukya king (973-997) who granted Ranna the title of Kavicakravarti.

28 kannaranādaradịn kuḍe / ponnam manamosedu tailapam kuḍe rannam / mannisi ballālam kude / jannam kavicakravartipesarampade [dam ] [dar] || 1.21.

29 Nephew and disciple of Harihara, author of a fundamental text of the Śaivabhakta tradition, the Hariścandra caritra. He contributed, together with Harihara, to the development of a new kind of poetry in ragale and șatpadi meters. On this figure, see the account from Canna Basava Purāna: 62,56-58. 
In view of his link to the court, it is all the more interesting to examine how Janna engaged himself in the "public narrative" of the time.

Let's then try to understand how the poets used the public narrative as a poetic, literary genre by focusing on an illuminating inscription composed by Janna in 1197, a few years before the Yaśodhara carite. This inscription is found in the temple of Amrteśvara in the village of Amrtapura-in the northern part of the Hoysala realm, at the border of the Câlukya realm, in the Tarikere area of the Chikmagalur district. Notably, the other inscription attributed to Janna is a copper plate located in the south of the region, in Cannarāya Pațana (Anekere), somehow mapping the borders of the kingdom, and it is dated 1190. This earlier inscription also records a grant of a minister of Ballāla II, Māca. It is much shorter, though, and it is less experimental: it presents many of the stylistic features of Janna's inscription in Amrteśvara, as I will discuss during the following part, but the figure of the minister and his relation to the king is much more conventional.

The temple of Amrrteśvara ${ }^{30}$ was erected in 1197 by one of the commanders (dandanāyaka) of Balläla II, Amita, ${ }^{31}$ who is the central character of the inscription together with the Hoysala kings. Amita belonged to a merchant community ${ }^{32}$ and was most likely in charge of this area. On the one hand, Amita could afford to build a temple as lavish as that of Amrteśvara, rich in carvings and sophisticated architecture; this in itself indicates the growing power of the royal elite. On the other hand, as the inscription will show, we would deeply misunderstand the historical context and the relationship between the king and the elite if we were to read this temple as a sign of a loss of regal power. Ballāla II is represented as the higher instance from whom the power comes: It is indeed from Ballạla that Amita receives the land to grant as an agrahāra. ${ }^{33}$ Moreover, the sacred area with its fully developed Hoysala-style architecture and novel narrative focus on the Mahäbhärata and Rāmāyaṇa, ${ }^{34}$

30 See Foekema 1994: $7^{6-79}$. The name of the temple is chosen to echo that of the commander, Amita.

31 See Coelho 1988: 167.

32 Amita's father was Hariyana Setti.

33 śrimat-pratāpa-cakravarttivīra-ballāla-dēvara śri-hastadị̣ dhārā-pūrvvakaṃ padedu [...] āsandi-nāḍ-olagan-agrahära-hunaseyakațtavam sarvvanamasyav [em: sarvvamānya] àgi kottta datti: (ll. 102-106) "Having ritually received (the ritual pouring of waterdhārā-pūrvvakam ) from the hands of the valorous emperor Vīra Ballāla Deva, he donated, exempted from taxes, the village of Hunaseyakatta—which was part of an agrahära—in the district of Āsanadi."

34 Sculptural adaptations of stories from the two Indian epics was already a practice at the time of Viṣnuvardhana, but such work increased exponentially during the reign of Ballāḷa II (see Evans 1997). 


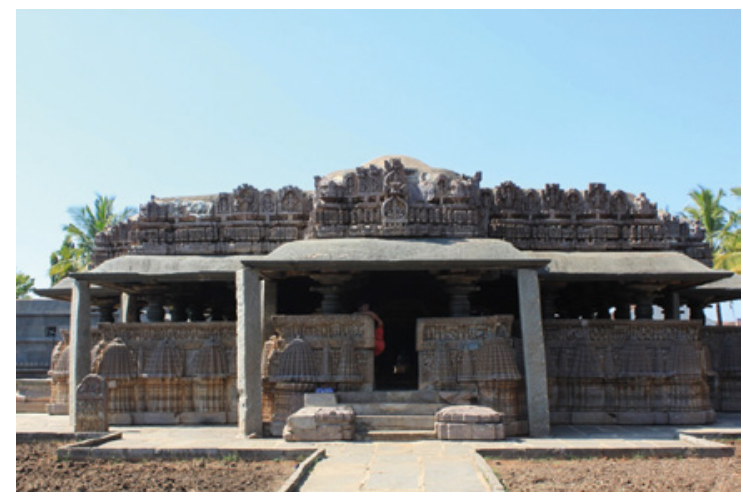

Amṛțapura, Amṛteśvara temple PHOTO C. BIGNAMI

whose stories decorate much of the outer wall of the temple, signals the presence of the Hoysala king and his elite.

It is in this context that Janna, court poet of Ballāla II, who at this time was in the north fighting the Câlukya and the Paṇdyas of Noḷambavāḍi, composed a one-hundred and twenty-line-long inscription to mark the erection of the Amrrteśvara temple in Amṛtapura and the donation of the land. If we look briefly at the structure of this inscription, catalogued in Rice's Epigraphia Carnatica as Tk 45 (EC VI), we notice that it contains all the typical parts of a stone royal inscription (see Schmiedchen 2014):

1- mangalācarana: invocation to Śiva in Sanskrit, as was common. ${ }^{35}$ (1 line, 1 l.)

2- Brief praise (praśasti) and invocation of protection for Amita, the commander and donor. (5 lines, 2-6 ll.)-Absent in the earlier inscription of Cannarāya Pațtana (EC v: Cn 179).

3- Genealogy of the Hoysala with an account of the foundation legend, and a long excursus on the figures of Ballāla II (17 lines out of 43). (43 lines, 6-52 ll.)

4- Genealogy and praise of the brothers of the commander Amita and long praise of the commander himself. (47 lines, $5^{2-99}$ ll.)

5- Account of the erection of the temple and donation of the land. (17 lines, 99-115 ll.)

6- Colophon, i.e. statement of the authors of the inscription. Final verse and further names of the recipients of the donation. (7 lines, $115^{-121} \mathrm{ll}$.)

35 For the choice of language in inscriptions, and the development of the division of labor involved, see Pollock 2006: 120-121 and cp. 10.1. 
A similar structure is also found in the inscription $\mathrm{Cn} 179$, but there is no initial reference to the minister, as is more common, and his genealogy is only briefly listed.

Yet, if we were to dismiss Tk 45 as one inscription among many others of this type, we would miss its significance in relation to the other compositions of Janna and to the questions we posed earlier as to the literary nature of the work and its relation to the representation of power structures. In the following section, I hope to show that this inscription is a poetic act in its etymological sense. It is an act of crafting reality. Not only the figure of the king, but the entire inscription is built around a series of figures that echo each other, resembling a game of mirrors. In fact, the whole inscription is infused with references to the idea of duplication and similarity, which further magnifies differences. At the end, the "replica" of the king as the commander is simultaneously an intensification and a diffusion of the image of the king. The inscription, moreover, acts as a mirror itself, subtending an everchanging gallery of images.

\subsection{The Poetic Voice of Janna}

I would argue that the text of the inscription is conceived and constructed as a poetic act (kavite), and that we can observe this through different layers. Let's start from the end, where, surprisingly, we find a complete colophon ${ }^{36}$ stating all its artifices. Here, the inscription is clearly presented as a literary composition (racane) constituted by three components: "The Bhālanētra of great poets, the friend of good poets, Jannayya's poetry. The coiled leaf in the ear of Sarasvatī, of pleasing form, Lokkiguṇịi Mahadēvaṇnạ’s disciple Nākaṇna’s writing. The superlative leader of titled engravers: the sculptor Mallōja's inscription."37

The declaration of the composer, however, is not the most defining element. To hear the voice of Janna, we have to scrutinize the textitself:Janna has carefully composed the inscription Tk 45 as a campū, arranging together gadya, kanda, $v r t t a$ and vacana. He uses different meters (campakamäle, mattēbhavikrị̄ita) that skillfully interchange in specific parts of the text. Janna alternates kanda and $v$ rtta meters when presenting the Hoysala genealogy and that of the chief

$3^{6} \quad$ Inscriptions that end with a statement of the scribe are not rare; less common are those where both the scribe and the sculptor are mentioned, or the sculptor and the poet. In this case we have all three names: poet, scribe, and sculptor. This circumstance is far from unique but is not commonplace. The inscription $\mathrm{Cn} 179$ also contains all three names, but they are simply listed without attribution. 
commander, Amita. This rhythm pauses at precisely two moments, namely, for the two main characters of the poem: Ballāla II and Amita. Ballāla II is praised in kanda meter and Amita in gadya or better, gadyakārya. Thus, already at the prosodic level, Janna makes use of sounds and rhythm to direct attention to the core of his story, the king and his commander. Yet, the intention of the poet to create a literary piece and to give voice to his own imagination goes far beyond the metrical level.

As is common in royal inscriptions, here, too, the life of the Hoysala kings, their deeds and qualities, are represented as part of the eulogy. The poet, however, embeds it into a poetic frame. He abides by the compulsory metric conventions, such as the use of dvitīya $k$ șara prāsa, ${ }^{38}$ and he employs various stylistic devices such as onomatopoeia, anaphora, figura etymologica and other figures of speech and of thought.

This refined language is not just a display of poetic skills; it is used to paint a wider picture in which each scene morphs into a sculpture through Janna's iconographic grit and adds up to a "triumphal arch" of the Hoysala dynasty. The poet consistently portrays each Hoysala king through the evocation of topical moments that are deftly molded in front of the eyes of the reader. Sometimes this is executed through a few strokes, as for Viṣnuvardhana, Ballāla II's grandfather, and the seven Konkan kings casting down their weapons and falling into the sea. ${ }^{39}$ Sometimes, it is shown through a brief dialogue, such as the one between Ballāla I and the Malava emperor:

(vṛtta)|| kālegadol taḍanigaḍidu mundaṇa thațtin avun̉ki pāydoḍ ā- | mālava-cakravartti Jagadēvane tanna madāndha-sindhuram | kịl iḍe pūtu rāvutene rāvūtan allen idirccu vīra-Ba- | llālan en endu mețti tivid āltanav accariy āytu dhātriyol || ll. 23-25

When he (Ballāla I) struck the intoxicated elephant of Jagadeva while pushing back the army that was rushing to attack him, that Malava emperor said to him, "Well done, O horseman". Ballāla answered, "I am not a horseman, I am Vīra Ballāla, fight me" and he trampled on him. The world wondered at his prowess.

${ }_{3} 8$ dvitīya $\bar{a} k s a r a$ prāsa: a prosodic figure in which in the second position of each verse the same syllable (akșara), more precisely the same consonant, is repeated. This stylistic device was commonly used also in Malayalam and Tamil poetry. See, for example, the first verse quoted below, ll. 23-25.

[...] kayduvikki kaḍalo! padaliț̣udu sapta-końkaṇam || l. 26. 
In other cases, such as for Narasimha, Janna's taste for the sensorial, worldly existence emerges more strongly:
(vṛtta) || kedaritt aḷittu baḷitt agidud ugidud asmad-baḷaṃ nillad inn $\overline{\mathbf{l}}-1$
padadol kaikolven end oḍ̣̣ idiroḷ odavi nissāṇamaṃ tāne sūlai- | sidan attal taipu māṇ mārmmaledoḍe talegoṇ̣ ettidạ̣ tungabhadrā- | nadiyaṃ pāṇ̣̣āvanībhṛd-baḷada peṇagaḷim kaț̣idaṃ nārasiṃhaṃ ||
11. $31-33$

"My army has dispersed, set back, frightened. I will not stay still. Now it is the time to intervene". Thus, Narasimha himself prepared to fight in the front. He himself beat the drum. At that time when the army of the enemy attacked wildly opposing him, Narasimha confronted them and filled up the Tungabhadra river with the corpses of the Pạṇ̂ya's troop. The river rose.

Alongside Janna's poetic sensibility, the burning of the forest at the hands of Ballāla II becomes a cluster of onomatopoeic words, and the sounds of the conflagration are intertwined with the visual metaphor of blood coming out of the headless body of the army that is compared to a forest.

uriyant ant atțeyim suț̣ urisi negeye nettar mmahī-cakradọ ka- | ggarikentant ettalum pandale paḍaliḍe dhaṃ dhaṃ dhagil bhur bhugil gham |

gharị̣ end ēn alvitō sēvuṇa-baḷa-vanamaṃ vīra-ballāla-kōpō- | ddhura-dāvōgrānaḷạ̣ śātrava-ṇ̣pati-mṛga-brātam aḷāọuvannaṃ ||

11. $42-44$

Blood was gushing as from a tree-trunk completely consumed by fire, and trees and creepers were falling on every side-dham dham dhagil bhur bhugil gham gharil [swish, ka-boom, whooo, hiss, boom, crack]-that's how it was when the wildfire of Ballāla's rage burnt ${ }^{40}$ the forest that was the Sēvuna ${ }^{41}$ 's army, and the enemy troops were like terrified animals.

\footnotetext{
40 The verb alvitō with -ō at the end expresses the surprise, the wonder in front of the wild uncontrollable fire that is the fury of Ballāla II.

41 Sēvuṇa or Sēvaṇa are the Yādavas of Dēvagiri, near Bankapur, in northern Karnataka.
} 
The Sēvunaa's army are doomed to an analogous destiny in the other inscription composed by Janna in 1190 (EC V Cn 179).
innuṃ bīrada tōra-bittan agevoydant irppud ārūọha-sam | pannaṃ dakṣina-cakri gelda sorațūriṃ beḷvolaṃ muț̣e saṃ- | channōdghṛșța-kṛ̣īvaḷāvalị-hạa-prāgbhāga-niḥkīlitō- | tpannaṃ sēvuṇa-sainya-sad-bhața-karōṭi-kōṭi-saṃghaț̣anam \|| (ll. 64-69)

When farmers worked their fields, the tips of their ploughs smashed into millions of skulls of warriors from the Sēvuna army, the seeds sowed and left behind by the valiant emperor of the South as he conquered the land from Soratūr up to Beḷoḷa. ${ }^{42}$

We find a similar set of images, a similar graphic scenario, in Janna's depiction of the festival for Māri in the Yaśódhara carite (1.36-37). Here, the underlying upama $\bar{a}$ (simile) is between the spring and Māri's festival. If " $\mathrm{x}$ " is the spring and " $\mathrm{y}$ " is the festival (mārijatre), in the first stanza there is a rhythmic alternation of the two elements along the cadence $x-y y-x / x-y$, a kind of complex chiastic structure that repeats itself. Moreover, Janna's method of adaptation is a sign of his conscious refashioning: he takes a single metaphor from Vādirāja's Sanskrit version of the story (1.20) and stretches it over two verses. ${ }^{43}$

a dēviya jātrege moḷevōḍedẹ̣e vere sirada-gālạm

uriyuyyale kai-vōdasuke kōkila-dhvani

mūdaley-uliyāge baṃdudaṃdu basaṃtam || 36

sisira mane paḍedu parakege

basaṃtan alarvōda māvinadi maṃcikeyol

kusuridaridaḍaginaṃtevo

-l eseduvu tadvanadol udirda muttada mugulga! || 37

For the festival of that Goddess, the young moon, newly sprouted, was like the hook nailed into a man's head;4 ${ }^{44}$ the fire swung on a swing was

42 A similar metaphoric link between war and agriculture is adopted to a broader extent by Ranna in his Gadāyuddha (10.5). I thank Naresh Kirti for pointing out this intertextual connection.

43 I thank Eric Gurevitch for pointing this out to me.

44 This description evokes some practices of Māriyamma ritual where a man is hanged on a hook that perforates his head. 
like the spreading Aśoka branch; ${ }^{45}$ the call of the cuckoo was like mocking voices of the people - as spring arrived. (36)

The buds of the Flame of the Forest spread in the woods were like meat chopped in pieces under a flowering mango tree. Spring had slaughtered winter for the festival. (37)

Taking into account both the prosodic and the stylistic, semantic layers of what we have seen so far, we cannot but acknowledge that we are confronted with a conscious poetic creation. Packed with vivid images, it appeals intentionally and directly to the senses. As we have seen, in the Yaśôdhara carite reality has to be transmitted through a physical experience. Here, again, Janna's phenomenological attitude emerges, shaping an apparently conventional royal encomium and widening its scope.

Janna manages to create a small poem that integrates different aspects of his society by diffusely using common epic imagery to represent the Hoysala lineage's power and authority. Yet, Janna does something more. Apart from the usual eulogy of his patrons, it seems that, intertwined in the unfolding of the inscription, there is an underlying process of what I call "mirroring."

Let's take a step further. As we will see, Janna enacts the mechanism of reflection on three levels: those of the gods, the immortal nectar, and, finally, the portrayal of the commander. The core of Janna's creation lies in this portrayal of Amita who becomes the mirror-image of the king.

\subsection{A Spiral of Mirroring Images}

Looking at the whole text and its structure, what is the "deeper" story that Janna gives us in this poem? A strong indication appears at the very beginning, in the second stanza, where Hari and Hara are asked to be the protectors of Amita. They are depicted as held in the loving glances of their wives that make them look alike, and this resemblance confuses the devotees:

siriy-alargaṇ̣a beḷvalaginiṃ pudid ambujanābhan iśan-ant- | ire girijā-kațākṣa-rucigal pudid îsanum abjanābha-ant- | ire jana-saṃstavaṃ tamage pallațam appinam oppi tōruv ā- | hari-hara-dēvar old amitanam parirakșisut irkke santatam || 1l. 3-5

45 The Aśoka branch evokes the color red, as the branches are full of red flowers at that moment. 
Viṣnu (the one with a lotus in his navel), through the bright rays of Siri's ${ }^{46}$ lotus eyes falling on him, looks like İśa; and İśa, through Girijā's glances of favour falling on him, looks like Viṣnu; so that the devotion of their followers is confused between them. May these gods, Hari and Hara, protect Amita.

First and foremost, then, Janna portrays two gods whose similarity is so strong that it renders them as doubles-and this mirroring effect is produced by the loving glances of the wives. Moreover, these gods are placed in a central position from the start, since the beginning of each (good) story-telling foreshadows its core. One thing must be clear: the seed implanted from the beginning is not that of identity; rather, it is a mirroring effect where the two gods reflect one another but are not exactly the same. Moreover, it might be misleading to think here of the mirror as a metaphor of the tension between appearance and reality ${ }^{47}$ We have no original and no copy, but rather two almost identical gods, reflecting each other.

Let's move to a second instance of mirroring images: that of the immortal nectar, amrta. Janna integrates political motifs, merging local and translocal elements through a series of echoes. The poet embeds epic references throughout the composition, such as the common connection of the king with Rāma, the king par excellence. Viṣnuvardhana is portrayed as "a Rāma" in one passage that mentions the performance of the Vedic rituals of hiranyagarbha and tulāpuruṣa:

dhuradọ viṣnu-ṇ̣paṃge dig-vijayad udyōgaṃ baraṃ nilva-bhū- | varar ār ā-ṇ̛ipa-rāman ettuvudu bēr-ondarkk ad ēk en tụ̣ā- | puruṣakk endu hiranyagarbbham irai end uttumga-dēvālayō- | tkaramaṃ māḍisal endu sanda pararāșțraṃgalge tān ettuvaṃ || ll. 28-29

While King Viṣnu was on his expedition of victory, what kings could stand before him? In the same way that lord Rāma rose high, foreign kings turned to acts of charity and occupied themselves with the tulapurușa, hiranyagarbha, and the building of temples.

A few lines later, Ballāla II is said to be a Rāma in vitality and a Bhīma in firmness (calad-añka-Rāmam birud-an்ka-Bhìmaṃ) juxtaposing Rāmāyaṇa and

46 Tadbhāva for Sṛīi i.e. Lakṣmi.

47 See Shulman (2006:18) on mirrors as an interface for the different degrees of presence of the masked goddess who is seen through a mirror. 
Mahābharata, ${ }^{48}$ just as in the narrative panels on the outer walls of the temple both epics are fully represented.

But among the epic references, Janna foregrounds the immortal nectar, the amrta, duplicating and localising it in the territory and the temple. At the beginning of the inscription, he inserts the amrta that is in the name of the temple itself and that here becomes a mark of excellency, a measure of beauty, pleasure, and eloquent speech. ${ }^{49}$

śrīmat-sēnādhināthōttamanan amitanam rakṣisutt irkke tārā- |
stōmam nilvannegaṃn nārada-masṛna-rasa-vyakta-gītāmṛtam gau- |
rī-mugdha-snigdha-maṃda-smita-madhura-kațākșāmạtam dēvarāja- |
prēma-stutyādi-sad-vāg-amṛtan amṛtanātham trilōkaika-nātham ||
$\quad$ ll. 2-3

May the lord of the three worlds, Amritanātha, who has the nectar of tender songs sung by Nārada, who has the nectar of sweet glances in the beautiful, lovely, indulgent smiles of Gaurī, who has the nectar of speech in the praises of Indra, preserve the chief of generals, Amita, as long as the constellations stand.

Shortly thereafter, the reference to the amrta emerging from the ocean is used to recall the churning of the ocean and to establish the beginning of the long genealogy that connects the Hoysala with the Lunar lineage..$^{50}$ Janna depicts the classical Puranic genealogy starting from Brahma and passing through Purūravas and Yadu. After that, he includes Sala - the mythical founder of the dynasty - thus incorporating in the Soma vamisa, the local family goddess (the kuladevat $\bar{a})$ and the founding legend, ${ }^{51}$ which is also sculpted on the superstructure (vimāna) of the garbhagrha of Amṛteśvara temple:

48 The same syntagma is used for Ballāla II in Cn 179. The association of kings and commanders with main characters from Mahābhārata and Rāmāyana is a trait of Kannaḍa literature too. Suffice here to refer to the Vikramārjunavijaya by Pampa (also known as Pampabhārata) where the poet equates the figures of Arjuna and that of his patron, Arikesari II, throughout the poem.

49 It is worth noting that the name of the donor and central actor of this inscription, Amita, resonates with the noun amrta, of which it could be a kind of tadbhava.

50 The same agenda is seen in the Cālukya inscriptions of the time of Vikramāditya vi (10761126) against whom Viṣnuvardhana I waged war.

$5^{1} \quad$ As for the founding legend and its local elements and its variations, see Coelho 1950: 12-24; Alí 1972: 39-43; Bignami 2015; Mucciarelli 2016. 
(gadya) || ā-niśśaṃka-pratāpa-cakravarttiy-anvayāvatāram ad entendọ̣ amṛtad amṛtakarana kamaleya kaustubhada pārijātad airāvatad uccaiśravad accaraseyara sambhūtiyiṃ khyātigākaram āda piyūṣaratnākarada naḍuve \|

(vṛtta) || siriyaṃ kaustubha-ratnamaṃ hariyan aṃt ā-śan̉khamaṃ cakramam |

bharadiṃ pệi bahitrad-antir esed irddaṃ sẹṣan ā-kṣīra-sā- | garadoḷ dēvana nābhi-padmada mṛnāḷạ kūvakambambol a- |

ccariy āg irddudu karṇnadhāranavol irddam puțti padmōdbhavaṃ || ll. $6-8$

How to describe the descent of that emperor whose valor was beyond doubt? In the middle of the ocean of milk which is celebrated as the birth of the immortal nectar (amrta), the moon (whose rays are amrta) Lakșmi, the Kaustubha jewel, the coral jasmine tree (Pārijāta), the elephant Airāvata, the horse Uccaiśśrava, and the Apsaras;52

Like a ship laden with prosperity (Siri), the Kaustubha jewel, Hari, the conch and the disk, lay the serpent Śeșa; and in that milk ocean the stalk of the god's navel-lotus rose up like a mast. And Brahma was born like a shipmaster.

The amrta is, then, the god, the measure of excellence, and the origin of the Hoysala genealogy, right from the beginning of the world. As in the echoing sound, the same word is repeated without being exactly the same. In this case, too, we find the underlying rationale of a mirror that gives us a manifold image of the object, and we begin to grasp the kind of mirror with which we are dealing.

First, Janna has suggested a mirroring effect in his description of Harihara: a process of reduplication that clearly produces two quite similar, and yet not identical gods. Through the word amrta, Janna reaches a further level: the mechanism manifests fully its capacity to operate as a kaleidoscope and to generate a potentially infinite number of images. The mirror Janna implants beneath the surface of the text can project the object it reflects onto different spaces of meaning. We can now move to how he applies it to the core reflection, the one of the king and his commander, Amita. The second half of the inscription, which is entirely focused on Amita, is actually a mirror of the first.

$5^{2}$ This list recalls all the things that according to the Puranic myth were born out of the churning of the ocean. 


\subsection{Amita: The King's Double}

As we arrive full circle, to the final part of the inscription, we encounter the expected account of the consecration of the temple and the donation of the agrahära by Amita. In this part, a largely straightforward record of facts, the relation between the god Amṛteśvara, Amita, and his king Ballāla II, is reasserted by making the king the one who gives the land with the proper ritual (dhārā-pürvvakam $)^{53}$ to the commander who erects the temple.

This final part of the inscription accounts for the actual event that took place between Amita and Ballāla II. The long part that precedes it, however, is entirely about the creation of these two characters, who will fulfill the concrete "action" of the erection of the temple. This, I suggest, is the crafting of the king and his commander as mutual mirrors, balancing their power.

First, if we compare the structure of this inscription with those where the king is the main agent, the donor, we can see that the same elements used for the king are reduplicated for his commander, Amita. Moreover, Amita is in fact named at the beginning of the inscription as the only one who could conquer all the earth on behalf of the king. For the commander the protection of the gods is evoked. After the mention of Amita in the incipit, with his name present in each of the first three stanzas leading to the prose portion, there is a long digression on the Hoysala lineage. When Amita returns to the tale, the same pattern as for the king is put in place. After the invocation of the protection of the gods on him, the full genealogy is accounted for, followed by the praise of Amita's brothers, exactly as was done for the brothers of the king, Ballāla II.

Alongside the structural similarity, Janna had different topics reemerge in the second half of his inscription, where he focuses on Amita, the commander. As we have seen before for Viṣnuvardhana and Ballāla II, the commander, too, is associated with characters from the epic lore, again bringing together Mahābharata and Rāmāyaṇa:

kaḍu-valpim Bhīman embaṃ negaldan eḷeyol and ātan ind ìtan ant or- | nnuḍiyindạ̣ Rāman embaṃ negaldan eḷeyol and ātan ind ìtan ārggaṃ | kuḍuv-ārppiṃ Karṇṇan embaṃ negaldan eḷeyol and ātan ind ìtan iṃ pēl- | vaḍe matt ill ārum embant esedapan Amitam dạ̣danātha-Triṇētraṃ || 1l. $68-69$ 
Just an inch of his firmness, and he is now famous on the earth as that Bhima was then; just one word from him, ${ }^{54}$ and he is now famous on the earth as that Rama was then; for his generosity towards everybody he is famous now on the earth as that Karna was then. If you ask, there is nobody like Amita, the Śiva of the commanders.

Moreover, the commander's praise is elaborated and carefully carved like that of Ballāla II, as we read in this small portion from the long description of the army-chief's merits:

vijaya-gōminī-maṃgaḷāyatana-ratna-tōraṇanuṃ | caturtthakuḷa-kumudinī-śarac-candra-candrikōpamāna-mānānūna-sarvvalakṣaṇa-sampūrṇna-suggāmbikā-garbha-dugdhārṇṇava-pārijātanuṃ [...] yādava-kaṭaka-ratnābharaṇanuṃ | daṃḍanātha-mauḷimāṇikyanum | daṃ̣̣anātha-kusumakōdaṃ̣anum | daṃ̣anāthagaṃḍa-mārttaṃḍanuṃ | daṃ̣anātha-dik-kuñjaranuṃ | uddaṃḍadaṇ̣̣anātha-kọ̄̂āhaḷanum | vācālạ-daṃḍanātha-hāḷāhạ̣anuṃ || cōla-daṃ̣anātha-kāḷa-rākṣasanuṃ | mālava-daṃ̣anātha-madanatriṇētranuṃ [...] ll. 9o-91; 96-97

[Amita is] A jewelled portal for the auspicious home of the goddess of victory. [He is] A pārijāta tree from the ocean-like womb of Sugāmbikā; she had all the signs of full-fledged beauty and she is like the moonlight of the autumn moon for the waterlily ${ }^{55}$ of the Caturthakula; ${ }^{56}$ [...] [Amita is] a jewel ornament to the Yâdava lineage; a crest gem among his generals; the god Kāma ${ }^{57}$ among his generals; a sun among his fiery generals; a direction-elephant ${ }^{58}$ among his generals; he is chaos for the hostile generals, poison for the boasting (rival) generals; the demon of death for the Cọla generals, he burns the Mālava generals as the three-eyed Śiva burns Madana [...].

\footnotetext{
54 In the sense that he sticks to his word.

55 This very common image draws from the powerful effect of the moon on the waterlily that is said to open at the light of the moon, cf., e.g. kumudinīkanta that refers to the moon as the lover of the waterlily.

56 Epigraphists usually take this term as referring to the fourth jāti (śudra).

57 Kusumakōdaṇạ: "one who has a bow of flowers". This is an epithet for Manmatha or Kāma, the god of love.

$5^{8}$ Reference to the elephants that stand in the four or eight quarters of the sky.
} 
Amita seems to have everything it takes to be a king, including the beauty and charm that are conditio sine qua non of royal power:
kēraḷa-nitambinī-tāra-hāranum | mālava-māninī-manō-rañjananuṃ karṇnāța-kāminī-karṇnābharaṇanuṃ | pradhāna-jangama-kēdāranuṃ | ll. $98-99$

A shining garland for the Kerala women; exciting the love of the disdainful Mālava women; an earring for the affectionate Karṇātaka women; a Kedāra ${ }^{59}$ for the chief of the Jangamas (Śiva devotees).

One might think that so many scattered projections of the king onto the commander, and vice versa, render the two so similar that their subjects- just as the devotees of Harihara-will be confused. Yet that does not happen. A small variation is going to impair the linearity of the symmetry. In fact, the dynamic of similarity reaches its apex when Janna establishes a direct link between the commander and the god. And at this very moment the similarity is shattered. The boon of the god is usually attributed to the king, and it is the sign of divine protection for the Hoysala. It also represents a central component of the foundation legend: the family goddess Vasantika gave the boon of land to the founder of the Hoysala dynasty. In our inscription the boon of the god is attributed to Amita, the commander:

svasti samasta-bhuvana-rāja-rāji-virājita-cūḍāmaṇi-marīci-mañjarīrañjita-caraṇa-nalina śrīmad-amṛtēśvara-dēva-labdha-vara-prasādanum [...] 1l. 88-89

Hail! The clusters of rays from the shining crown-jewels of the array of the kings of the entire world light up your lotus-feet; you obtained the boon of the god Amṛteśvara.

A parallel expression is used for Ballāla II. In this way, the boon, the selected gift, is also duplicated; but it is slightly different one-like an image in a convex mirror-as here it is the god Amṛteśvara and not the goddess who gives the boon. This small difference that lies at the core of the description of Amita

59 Kedāra is one of the names for Śiva referring to the place in the Himalaya identified by the Sivapurāna tradition between the 1oth and the 13th centuries as one of the twelve jyotirlingas (see Bisschop 2006 and Fleming 2009). 
breaks up the similarity between him and his king. It shatters the continuum of correspondences.

Up to this point, Janna has conjured a growing accumulation of quasireplicas: first through the two gods Hari and Hara, then through a polymorphic nectar of immortality (amrta). Finally, the structure of the inscription is built upon symmetrically repeating patterns. The poet has hence constructed a veritable room of mirrors. This room is inhabited by the king and his commander, Amita, who seems to be the replica of the king. At this point, something decisive takes place. The invisible mirror again operates on the king and on Amita, his commander, projecting a core feature of the royal power: the boon from the divinity.

The reduplication becomes a source of power through its connection to the divine. This apical reflection, this echo, apparently destroys the uniqueness of the divine boon itself. Two boons emerge from the continuous spiral-like process of mirroring: one from the goddess and one from the gods. They are almost the same, and yet not exactly the same, as an object whose perimeter is blurred and thus seems to occupy at the same time different areas of space. By way of embedding, Janna has expanded the mechanism of mirroring that is inherent to inscriptions, and he uses it as a device to praise both the king and the commander. At the same time, he has inserted them in an asymmetric universe, full of projections, of quasi-replicas, of simulacra - that is, a world threatened by confusion. The power of the king as well as that of the elite are always on the verge of being overwhelmed by chaos. ${ }^{60}$ In this way, Janna added his personal, somewhat ironic, touch to the usage of inscriptions in the symbolic representation of royal power. ${ }^{61}$

In this article, I examined an inscription that is an account of the donations accompanying the installation of the temple of Amrteśvara by Amita, a chief commander of the Hoysala king, Ballạla II, in 1197. The inscribed text was composed by one of the most influential court poets of medieval Kannada literature, Janna, who, while adhering to the common structure of royal inscriptions, crafted a powerful piece of public narrative. Through the use of various

6o On the precarious and transient nature of kingship in South India there is a considerable scholarship. I mention here, by way of example, Stein 1977, Dirks 1979, and Shulman 1985.

61 On the symbolic representation of power, see, among others, Narayana Rao, Shulman, and Subrahmanyam 1992. 
stylistic devices and imageries, he conjured a refined and articulated campu in which different elements are merged: the negotiation of power between the king and the elite, the localisation of pan-Indian elements, and the relation between the centre of the kingdom and its periphery, where the temple of Amṛteśvara is located.

Moreover, Janna placed his composition in ongoing dialogue with contemporary political developments. Increasingly in this period, the king was seen in the form of a god, an agent of the central cult. Thus, he had to be identified with the local god in order to approximate the sacred domain represented by the temple. ${ }^{62}$ In relation to the processes of negotiating power within the enlarged Hoysala territory, the commander undergoes in this inscription a process similar to that of the king. In this sense, it is not just a matter of constructing kingship, but rather a case of negotiating elite identity, an essential aspect of the royal agenda that runs throughout the history of medieval South Indian Kingship. ${ }^{63}$ Our inscription can be understood as a political statement on the part of the king and of the ruling elite. The commander is not trying to present himself as a king; the hierarchic relation is clearly stated in the account of the foundation itself, where the king is the mediator between Amita and the land. Rather, the rulers had to mediate between the different groups that gained control over the territory.

These historical and political issues partially constitute creative core of the inscription. Yet, if left on its own, this analysis would fail to capture a constitutive component of what we have as documentation of the intellectual and cultural history of medieval Karnataka. The text of the inscription is also a personal testimony of poetic subjectivity as well as a depiction of the play between reality and appearance. Rulers used to build replicas of temples in the periphery of their reign. Similarly, the commanders being represented as projections of their kings were meant to enhance by means of resonance the power of the rulers. The poet took this mechanism and turned it into the dominating motif of his inscription by putting the motif itself in action in the poem.

62 The temple both represents the central cults and constitutes the locus of bhakti and the symbol in the material spaces of sacred domains. The king creates the link between these two through his identification with the local divinity and through surrendering the temporal power to the divinity. On the role and complex reality of the temple, see Chattopadyaya 1995: 209-211; and Appadurai 1976.

63 On the ongoing power negotiation between the king and the various elites and the complex dynamics connected with South Indian kingship, see, among others, Shulman 1985 and, especially on Cola's lordship, Heitzman 1997. 
A mirror is a visual statement. ${ }^{64}$ It can be tilted this way or that, showing different perspectives on the reflected object in it. Mirrors allow for angles and variations, for multiplicity. A mirror somehow broadens by way of inclusion. ${ }^{65}$ More precisely, it permits you to see what you cannot see. What is that we cannot see? I think that a possible answer lies in the type of mirror Janna deployed. As we have observed both for the immortal nectar and for the divine boon, the mirror operates as a kaleidoscope. It fragments reality but leaves all the pieces connected.

In this sense, if we think of the locality that connects in a wider network to the trans-local through replicas, a mirror allows for an altogether different type of linkage. Mirrors bring elements together dialogically, modelling reality while also impacting that reality. A kaleidoscope-like mirror creates the possibility for flexible relations, like a fourth dimension between the different geographical and cultural strata. By way of projection, the mirror permits different perspectives. We should bear in mind that the Amṛteśvara temple is in the northern part of the Hoysala kingdom. In other words, the local power was trying to connect with a larger network and the same time hold within itself different social groups. Janna models this enterprise as the co-existence of multiple planes of reality affecting each other through a polymorphic projection.

In other words, Janna designed an inscription that acts as a mirror that reflects itself, in the multiple readings implied by its mediality. The dialogue between the king and the commander is the first mirror. All around this invisible mirror, a thousand mirrors will follow, reflections, echoes of those reading, repeating, copying the inscription, as we are doing now. But, more importantly, the king is reflected in the commander, who should act as an emanation of the king, expanding his control and, of course, immortalizing it. ${ }^{66}$ Amita becomes

64 As a topic, the mirror has engaged many thinkers. It will suffice to recall here Rilke's verse (Rilke 1923: II,3) "Spiegel: noch nie hat man wissend beschrieben, was ihr in eurem Wesen seid"; "Mirrors: never yet has anyone knowingly described, what you are in your essence".

65 On the inclusivity of the mirror, see, albeit the metaphysical implications, Plato, (Rep. $x$,

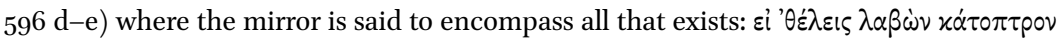

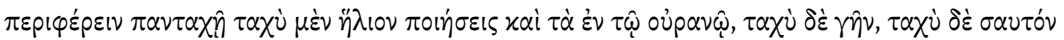

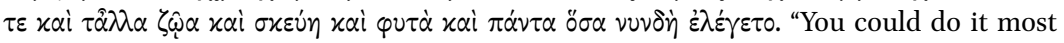
quickly if you should choose to take a mirror and carry it about everywhere. You will speedily produce the sun and all the things in the sky, and speedily the earth and yourself and the other animals and implements and plants and all the objects of which we just now spoke." See also Borges 1999: 107.

66 Dandin points out this quality of mirror (ädarśa) precisely in relation to kings: ādirājayaśobimbam ādarśam prāpya vāñmayam / teșām asaṃnidhāne 'pi na svayam paśya naśyati // (Kavyādarśa 1.5) "Once it finds a mirror made of words [to be reflected in], the body/icon/form of the early kings' fame, doesn't vanish, see! Even after they [the kings] are gone." 
another form of Ballāla. And yet, not exactly the same-hinting at the very confusion we note at the beginning of the inscription with the gods Hari and Hara. By way of different imaginaries, Janna forges an escalating accumulation of mirroring effects and uses this motif to subtly crack the apparent linear enhancement of power. The unique voice of the poet hints at the instability of the political and social system by introducing a defiling non-symmetric element, the divine boon, right at apical moment of the mirroring process.

Janna integrates politics and poetics, and, if we follow him carefully, we also grasp the holistic nature of the network that is composed by local, trans-local, political, social, economic, and artistic features as non-discrete elements. Holism is a thread that runs through our inquiry. If we consider that inscriptions, together with temples and courtly literature, functioned as effective means of communication and at the same time powerful means of expression, it follows that their analysis calls for a holistic approach. In turn, such an approach may shed light on how expressive media worked in twelfth-century Karnataka and what type of knowledge they entailed. In this vein, epigraphic documentation is not just a source of data, but also a complex mechanism in which singularity and multiplicity - the singular authorial voice within its broader historical context—present themselves for scholarly scrutiny.

\section{Acknowledgments}

This article wouldn't have come to light without the propelling encouragement of Yigal Bronner and Ma'ayan Nidbach; and it wouldn't be the way it is without the poetic sensibility of David Shulman, the intellectual generosity of Naresh Keerthi and the refined thinking of Ynon Wygoda. The research could be brought forward as part of the ERC-funded project NEEM. Finally, I would like to thank the anonymous reviewer for the insightful comments.

\section{Bibliography}

Ali, B.S. (ed). 1972. The Hoysala Dynasty, Mysore: Prasaranga.

Appadurai, A. \& C. Appadurai Breckenridge. 1976. "The south Indian temple: Authority, honour and redistribution." Contributions to Indian Sociology, 10 (2), 187-211.

Ben-Herut, G. 2105. "Figuring the South-Indian Śivabhakti Movement: The Broad

Narrative Gaze of Early Kannada Hagiographic Literature." The Journal of Hindu Studies 8, no. 3, 274-95.

Ben-Herut, G. 2018. Siva's Saints: The Origins of Devotion in Kannada According to Harihara's Ragalegalu. New York: Oxford University Press. 
Berti, I. et al. (eds) 2017. Writing Matters: Presenting and Perceiving Monumental Inscriptions in Antiquity and the Middle Ages. Berlin: De Gruyter.

Bignami, C. 2015. "Belur, the royal tirtha of the Hoysala dynasty. The >miscellanear of local elements contained in a sacred place". In T. Pontillo, C. Bignami, M. Dore, E. Mucciarelli (eds.) The Volatile World of Sovereignty: The Vrātya Problem and Kingship in South Asia. Delhi: DK Publishers, pp. 464-498.

Bisschop, P.C. 2006. Early Śaivism and the Skandapurāṇa: Sects and Centres. Gröningen: Egbert Forsten.

Borges, J.L. 1999. “Mirrors”. In A. Coleman (ed.) The Maker (1960), Selected Poems. New York: Viking.

Chattopadhaya, B. 1995. "Political Processes and the Structure of Polity in Early Medieval India”. In H. Kulke (ed.) The State in India 1000-1700. Delhi: Oxford University Press, pp. $195^{-232 .}$

Coelho, W. 195o. The Hoysala Vamsa, Bombay: Indian Historical Research Institute.

Cox, W. 2016. Politics, Kingship, and Poetry in Medieval South India: Moonset on Sunrise Mountain. Cambridge: Cambridge University Press.

Dirks, N.B. 1979. "The structure and meaning of political relations in a south Indian little kingdom". Contributions to Indian Sociology 13, 169-206.

EC V = Rice, B.L. 1902. Epigraphia Carnatica. 2 Vols. Mangalore: Basel Mission Press.

EC VI = Rice, B.L. 1901. Epigraphia Carnatica. Mangalore: Basel Mission Press.

Evans, K. 1997. Epic Narratives in the Hoysala Temples. Leiden: Brill.

Fisher, Elaine M. 2017. Hindu Pluralism: Religion and the Public Sphere in Early Modern South India. South Asia across the Disciplines. Oakland, California: University of California Press.

Fleming, B.J. 20o9. "Mapping Sacred Geography in Medieval India: The Case of the Twelve Jyotirlingas." International Journal of Hindu Studies 13, no. 1, 51-81.

Foekema, G. Hoysala Architecture. Vol. I: text, figures and maps. New Delhi: Books \& Books.

Francis, E. 2013. Le discours royal dans l'Inde du Sud ancienne: inscriptions et monuments pallava (IV eme-IX eme siecles). Tome 1: Introduction et sources. Louvain-la-Neuve: Institut Orientaliste.

Heitzman, J. 1997. Gifts of Power: Lordship in an Early Indian State. New Delhi: Oxford University Press.

Kasdorf, K.E. 2013. Forming Dōrasamudra: Temples of the Hoysala Capital in Context. PhD Diss.: Columbia University.

[Kavyādarśa] Tatacharya, D.T. (ed.) 1936. Kāvyādarśa of Dandin, with the commentaries of Vādijañghāladeva and Taruñavācaspati and the anonymous gloss. Tirupati: Shrinivas Press.

Krishnakumar, C.P. (ed.). 2007.Janna Samputa. Hampi: Prasaranga Kannada University. 
Kulke, H. 1993. Kings and Cults. State Formation and Legitimation in India and Southeast Asia. Delhi: Manohar Publishers \& Distributors.

Kulke, H. (ed.). 1995. The State in India, 1000-1700. Delhi-New York: Oxford University Press.

Meyer, E.A. 2011. "Epigraphy and Communication". In Pechin, M. (ed.) The Oxford Handbook of Social Relations in the Roman World. Oxford University Press: Oxford, pp. 191-226.

Michael, R.B. 1983. 'Foundation myths of the two denominations of Varaśaivism: Viraktas and Gurusthalins'. The Journal of Asian Studies, 42, 309-22.

Mucciarelli, E. 2016. "The Talking Stones: Royal Inscriptions in Medieval Karnataka." In Cosmopolitanism and Regionalism in the Indian Cultural Dynamics. Cracow Indological Studies, 265-298.

Murugaiyan, A. (ed.) 2012. New Dimensions in Tamil Epigraphy. Chennai: Cre-A.

Nagaraj, D.R. 2003. "Tensions in Kannada Literary Culture". In S. Pollock (ed.) Literary Cultures in History. Berkley: University of California Press, pp. 323-382.

Narasimhacharya, R. 1988. History of Kannada Literature. Delhi: Asian Educational Service.

Narayana Rao, V., D.D. Shulman, and S. Subrahmanyam. 1992. Symbols of Substance, Court and State in Nāyaka Period Tamilnadu. Delhi: Oxford University Press.

Panciera, S. 2012. "What Is An Inscription? Problems Of Definition And Identity Of An Historical Source." Zeitschrift für Papyrologie und Epigraphik 183, 1-10.

Pollock, S. 2006. The Language of the Gods in the World of Men. Berkley: University of California Press.

Pollock, S. 2013. "Festschrift Rajendran. Praśasti and its Congeners: A Small Note on a Big Topic." In N.K. Sundareswaran (ed.) Rājamahimā. Calicut: Calicut University Press, pp. 21-39.

Ramachandra, C.N. and B.A. Viveka Rai. 2015. Classical Kannada Poetry and Prose: $a$ Reader. Hampi: Prasaranga Kannada University.

Rilke, R.M. 1923. Sonnete an Orpheus. Leipzig: Insel Verlag.

Roda, I. 2012. "Epigraphy and the Media". In Davis, J. and Wilkes J. (eds.) Epigraphy and the Historical Sciences. Oxford University Press: Oxford.

Salomon, R. 1998. Indian Epigraphy. A Guide to the Study of Inscriptions in Sanskrit, Prakrit, and the other Inda-Aryan Languages. New Delhi: Munshiram Manoharlal Publishers Pvt. Ltd.

Sastri, N.K.A. 2005. A History of South India. From Prehistoric Times to the Fall of Vijayanagar. Delhi: Oxford University Press.

Schmiedchen, A. 2014. Herrschergenealogie und Religiöses Patronat. Leiden: Brill. Settar, S. 2014. Halagannậa Lipi, Lipikāra, Lipi Vyavasāya. Bangalore: Abhinava.

Siegert, B. 2015. Cultural Techniques. Grids, Filters, Doors, and Other Articulations of the Real. Tr. by G. Winthrop-Young. New York: Fordham University Press. 
Shulman, D.D. 1985. The King and The Clown in South Indian Myth and Poetry. Princeton: Princeton University Press.

Shulman, D.D. 20o6. "Toward a New Theory of Masks." In D.D. Shulman and D. Thiagarajan (eds.) Masked Ritual and Performance in South India, edited by. Ann Arbor: University of Michigan.

Sircar, D.C. 1965. Indian Epigraphy. Delhi: Motilal Banarsidass Publ.

Sircar, D.C. 1966. Indian Epigraphical Glossary. Delhi: Motilal Banarsidass Publ.

Stein, B. 1977. "The segmentary state in south Indian history". In: R.G. Fox (ed.). Realm and region in traditional India. Durham: Duke University, 3-51.

[Vādirāja Yaśodharacarita] Krishnamoorty K. (ed.) 1963. Vādirāja's Yaśodharacarita. A Literary Epic With A Sanskrit Commentary By Lakșmaṇa. Dharwar: Karnatak University.

[Yaśōdhara carite] C.P.K [= Krishnakumar, C.P.] (ed.) 1994. Jannana Yaśōdhara carita: sampāadana mattu gadyānuvada. Davanagere: Nagarjuna Enterprises. 